\title{
CORRIGENDUM
}

\section{Mutated telomeres sensitize tumor cells to anticancer drugs independently of telomere shortening and mechanisms of telomere maintenance}

MA Cerone, JA Londoño-Vallejo and C Autexier

Oncogene (2007) 26, 1983. doi:10.1038/sj.onc.1210192

\section{Correction to:}

Oncogene (2006) 25, 7411-7420. doi:10.1038/sj.onc.1209727; published online 12 June 2006

Since publication of the above manuscript, the authors found errors in Figure 5. The correct version of Figure 5 is shown here.
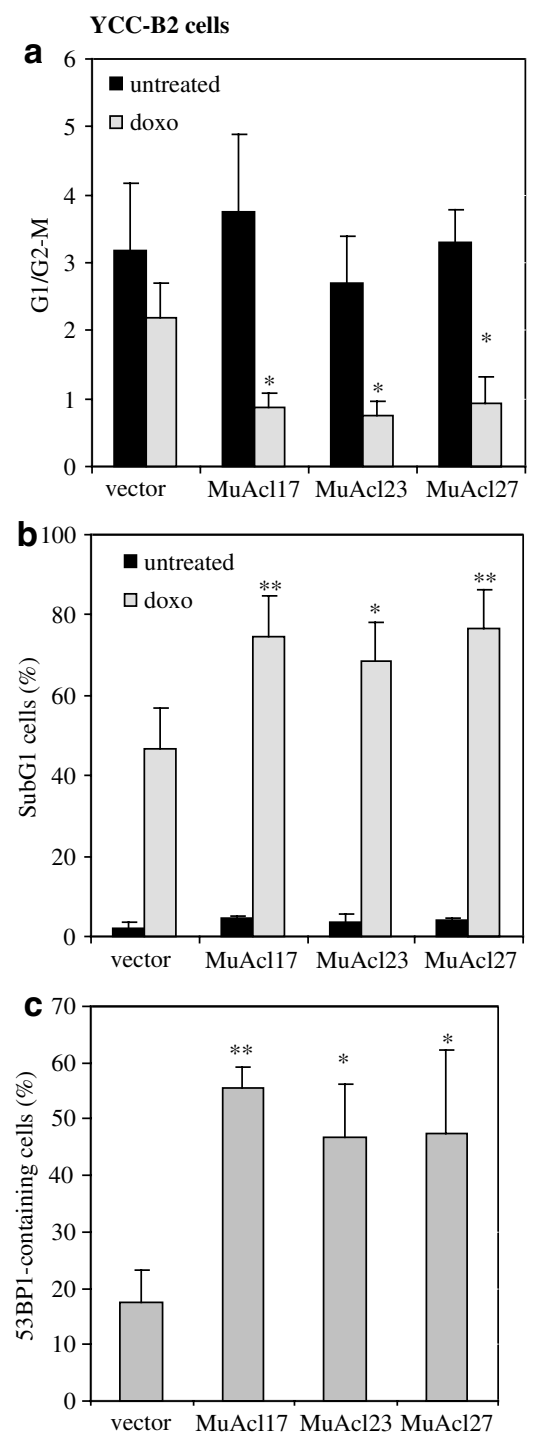